\title{
Properties of Strains of Sweet potato feathery mottle virus and Two Newly Recognized Potyviruses Infecting Sweet Potato in the United States
}

\author{
E. R. Souto, Departamento de Agronomia, Centro de Ciências Agrárias, Universidade Estadual de Maringá, \\ Maringá-PR, Brazil, 87020-900; and J. Sim, J. Chen, R. A. Valverde, and C. A. Clark, Department of Plant \\ Pathology and Crop Physiology, Louisiana Agricultural Experiment Station, Louisiana State University Agricultural \\ Center, Baton Rouge 70803
}

\begin{abstract}
Souto, E. R., Sim, J., Chen, J., Valverde, R. A., and Clark, C. A. 2003. Properties of strains of Sweet potato feathery mottle virus and two newly recognized potyviruses infecting sweet potato in the United States. Plant Dis. 87:1226-1232.

Some biological and molecular properties of six potyvirus isolates (LSU-1, -2, -3, and -5; 95-2; and 95-6) from sweet potato (Ipomoea batatas) were evaluated. Isolates LSU-1 and -3 and 95-2 were transmitted by Aphis gossypii and Myzus persicae while LSU-2 and -5 were not transmitted by either aphid. The partial nucleotide sequence of the nuclear inclusion $b(\mathrm{NIb})$ and the coat protein $(\mathrm{CP})$ genes of these six isolates were compared with the corresponding sequences of 17 Sweet potato feathery mottle virus (SPFMV) strains and 18 other potyviruses. LSU-1 and -3 had high sequence similarity to the published sequences for Sweet potato virus G (SPVG), did not react with antisera to other known sweet potato viruses, and caused distinct symptoms. We propose to designate these two isolates as SPVG. This report documents the occurrence of this virus in the United States and provides the first characterization of its biological properties. LSU-2 and -5 were distinct in symptomatology; partial Nib, CP nucleotide, and derived amino acid sequence; and serology to other viruses. We propose to call this virus (LSU isolates 2 and 5) Ipomoea vein mosaic virus. The present study revealed a high degree of sequence similarity between 95-6 and the common strain of SPFMV, and between 952 and the russet crack strain of SPFMV. Results from this study suggest not only that at least two strains of SPFMV occur in the United States, but that two other potyviruses also are present.
\end{abstract}

Additional keywords: ELISA, Ipomoea nil, I. setosa, I. tricolor, RT-PCR, serology, Sweet potato chlorotic stunt virus

Sweet potato has been identified as a crop that has great potential for alleviating food security concerns (28). However, because it is vegetatively propagated, it is prone to accumulate viruses and other pathogens. Sweet potato viruses are difficult to transmit mechanically, they occur in mixed infections, and their host range often is restricted to the family Convolvulaceae (24). These factors cause problems in detection, isolation, and identification of sweet potato viruses. Except for the most common strains of Sweet potato feathery mottle virus (SPFMV), the potyviruses infecting sweet potato have not been well characterized (24).

Corresponding author: R. A. Valverde

E-mail: ravalve@1su.edu

Nucleotide and amino acid sequence data can be found in GenBank as accession numbers: AF439637 (95-2), AF439638 (95-6), AY178989 (LSU-5), AY178990 (LSU-3), AY178991 (LSU1), and AY178992 (LSU-2).

Accepted for publication 21 May 2003.

Publication no. D-2003-0717-01R

(C) 2003 The American Phytopathological Society
Two strains of SPFMV originally were described and are distributed widely (23). The common strain, SPFMV-C, causes foliar symptoms but not root symptoms. Russet crack, a disease induced by a strain of SPFMV (SPFMV-RC) was thought only to be a problem on the 'Jersey' type of sweet potato (dry-fleshed), but not thought to affect the orange, moist-fleshed types including 'Beauregard'. However, in recent years, observations of a disease similar in appearance to russet crack have come from North Carolina, Virginia, California, and from isolated instances in Louisiana, Mississippi, New Mexico, and Texas (19; C. A. Clark, unpublished data). A SPFMV strain was reported in a sweet potato clone from Zimbabwe (10), but sequence data suggests that it could be regarded as a distinct potyvirus. Kreuze et al. (20) constructed a phylogenetic tree based on the coat protein $(\mathrm{CP})$ nucleotide sequence and recognized four distinct clusters; RC, comprising russet crack isolates form the U.S., Japan, and Korea; O, comprising isolates from several countries in Asia; EA, comprising isolates from East Africa; and the most divergent group, $\mathrm{C}$, for the common strain isolates. In addition, several other potyviruses have been reported recently from sweet potato, including Sweet potato chlorotic fleck virus (SPCFV), Sweet potato virus G (SPVG), and Sweet potato mild speckling virus (SPMSV) (27). It is clear that a complex of potyviruses affects sweet potato, but it is not clear how these various potyviruses relate to one another.

A reverse transcription polymerase chain reaction (RT-PCR) assay utilizing degenerate primers corresponding to the border sequences of potyvirus nuclear inclusion $b$ (NIb) protein and $\mathrm{CP}$ genes was used for specific detection of a severe strain of SPFMV in Japan (25). Moreover, SPFMV, Sweet potato latent virus (SwPLV) and SPVG could be detected by RT-PCR in 18 sweet potato clones from China (14). The sensitivity of PCR offers a potential advantage for detection of these potyviruses that are unevenly distributed and present at very low levels in infected plants. The universal presence of SPFMV often has masked the presence of other viruses in sweet potato, especially potyviruses, and hindered efforts to isolate and identify these viruses.

Although they can be detected by RTPCR assays, it is not yet possible to differentially detect each of the different potyviruses quickly, inexpensively, and efficiently enough to permit studies on their incidence and spread in the field. Among the sweet potato virus indexing methods, graft inoculation onto the Brazilian morning glory (Ipomoea setosa Ker.) is the most reliable (24). However, the procedure is time consuming and requires a great amount of labor and greenhouse space. The objective of this work was to compare some biological and molecular properties of six virus isolates of the family Potyviridae obtained from sweet potato from different regions in the United States and to evaluate the potential of RT-PCR for detection of SPFMV.

\section{MATERIALS AND METHODS}

Virus isolates. Sources of virus isolates were sweet potatoes showing SPFMV-like symptoms obtained from different locations. Isolate 95-2 was obtained from a Beauregard root grown in New Mexico that had russet crack symptoms, 95-6 from North Carolina, LSU-2 from Texas, and LSU-1, -3, and -5 from Louisiana. The common strain of SPFMV (SPFMV-C) 
was provided by J. W. Moyer, North Carolina State University, Raleigh. Viruses were isolated from the original sources by single aphid probe (Aphis gossypii) transmission for 95-2, 95-6, LSU-3, and -1 and after single local lesion transfers from Chenopodium quinoa for LSU-2 and -5. Isolates were maintained on $I$. nil 'Scarlet O'Hara' ( $\mathrm{SOH}$ ) by periodic mechanical inoculations. The potyviral nature of the isolates was determined by enzyme-linked immunosorbent assay (ELISA) using a monoclonal antibody for the potyvirus group (PTY 1; Agdia, Elkart, IN) that reacts with most potyviruses.

Host reactions. Various Ipomoea spp. (I. alba, I. aquatica, I. heredifolia, I. nil cv. $\mathrm{SOH}$, I. lacunosa, I. purpurea, I. cordatotriloba, I. tricolor cv. Heavenly Blue, and I. setosa), Nicotiana benthamiana, $N$. rustica, $N$. tabacum cv. Turkish, C. quinoa, and Datura stramonium were mechanically inoculated by grinding infected $I$. nil tissues in $0.02 \mathrm{M}$ phosphate buffer, $\mathrm{pH} 7.2$, amended with $0.1 \mathrm{M}$ sodium diethyl dithiocarbamate (DIECA) and rubbing the inoculum on Carborundum-dusted leaves. Leaves of I. nil plants that showed distinctive symptoms 2 to 3 weeks after inoculation were used as sources of inoculum. Seedlings of Ipomoea spp. were inoculated while in the cotyledonary stage. Graft inoculations to cv. Beauregard were conducted to determine if a synergistic reaction occurred between these isolates and a whitefly-transmitted isolate of Sweet potato chlorotic stunt virus (SPCSV) obtained from the sweet potato cv. White Bunch. Selected isolates were graft inoculated to I. batatas cv. Beauregard, previously infected with SPCSV. Sweet potato cvs. Beauregard and Jersey were inoculated with the individual isolates and storage roots produced on inoculated plants in the greenhouse were evaluated for russet crack symptoms.

Aphid transmissions. The green peach aphid, Myzus persicae, was maintained in insect-proof cages on mustard plants, and the melon aphid, A. gossypii, was maintained in separate cages on cotton. Prior to transmissions, aphids were placed on moist filter paper in a petri dish for approximately $1 \mathrm{~h}$ to fast. Individual aphids then were transferred to symptomatic source leaves of $I$. nil that had been mechanically inoculated 2 to 3 weeks previously. The aphids were observed with the aid of a dissecting microscope and were allowed to make a single probe into the source leaf. Approximately $15 \mathrm{~s}$ after initiating the probe, the aphids were gently nudged with a camel hair brush to encourage them to retract their stylets, and then were transferred with the brush to healthy 5- to 7-day-old I. nil seedlings of $\mathrm{SOH}$. After approximately $1 \mathrm{~h}$ on the seedlings, the aphids were removed and the seedlings were sprayed with imidacloprid. The exposed seedlings were incubated in the greenhouse for 14 to 17 days and the number of seedlings that developed symptoms typical of the virus isolate used was recorded. Transmissions were done on 10 occasions between October 2001 and March 2002 and, on each occasion, 3 to 6 seedlings were used for each virus-aphid combination. For statistical analysis, the percent transmission was determined and then converted by square root arcsin transformation for each combination and each transmission date was treated as a replication.

Electron microscopy. Leaf tissues from plants infected with LSU-1, -3, and -5 were fixed for electron microscopy studies with $4 \%$ glutaraldehyde in $0.05 \mathrm{M}$ cacodylate buffer ( $\mathrm{pH}$ not adjusted) for $2 \mathrm{~h}$ at room temperature, followed by three washings with buffer (20 min each). After post fixation in $1 \%$ osmium tetroxide for 2 $\mathrm{h}$, samples were washed briefly with $\mathrm{ddH}_{2} \mathrm{O}$ and stained overnight with $0.5 \%$ uranyl acetate at $4^{\circ} \mathrm{C}$. Infiltration was achieved with $50 \%$ (vol/vol) London Resin White in $100 \%$ ethanol. Blocks were polymerized at $70^{\circ} \mathrm{C}$ for $8 \mathrm{~h}$. Ultrathin sections were stained in lead citrate and observed using a Jeol transmission electron microscope.

Serology. In preliminary indirect ELISA tests with antiserum to SPFMV-RC (18), isolates 95-2 and 95-6 reacted positively while the LSU isolates were negative or weakly positive. All isolates were tested against antisera to: a severe russet crack strain of SPFMV (provided by J. W. Moyer), Sweet potato mild mottle virus (SPMMV), SwPLV, SPCFV, SPMSV, a virus provisionally designated as 'C-6', SPFMV (provided by S. Fuentes and L. Salazar, International Potato Center, Lima, Peru), and an antiserum \#1395 made against a partially characterized sweet potato virus (6) (provided by A. Brunt, Horticulture Research International, Littlehampton, UK) using a modification of the membrane immunobinding assay method of Abad and Moyer (3) developed by the International Potato Center (CIP). Three leaf disks of approximately $1.0 \mathrm{~cm}$ in diameter were cut and ground in $4.5 \mathrm{ml}$ of extraction buffer made of TBS $(0.05 \mathrm{M}$ Tris- $\mathrm{HCl}, 0.5 \mathrm{M} \mathrm{NaCl}, \mathrm{pH} 7.5)$ containing $0.5 \%$ sodium sulfite. Samples were kept for $30 \mathrm{~min}$ at room temperature. After clarification, 50- $\mu \mathrm{l}$ samples were placed on nitrocellulose membranes and dried at room temperature. Membranes were blocked in 2\% low-fat milk in TBS for $1 \mathrm{~h}$ with gentle $(50 \mathrm{rpm})$ agitation. The blocking solution was decanted and membranes washed briefly with TBS containing $0.05 \%$ Tween (TBS-Tween). To remove the weak reaction that was observed in preliminary tests with healthy samples, the Moyer and Brunt antisera were cross absorbed for 45 min at $37^{\circ} \mathrm{C}$ with healthy tissue from the host plant being assayed. The healthy tissue was extracted in TBS containing
$0.2 \%$ sodium sulfite, $2 \%$ nonfat dry milk, and $0.02 \%$ sodium azide $(1: 25$, wt $/ \mathrm{vol})$. The remaining antisera were diluted in TBS-Tween $(1: 1,000$ from $1.0 \mathrm{mg} / \mathrm{ml})$. The first antiserum was added to the membrane and incubated overnight with agitation at room temperature. The membrane was rinsed four times for $3 \mathrm{~min}$ each with TBSTween and dried using blotting paper. The second antibody (conjugated goat-antirabbit enzyme diluted 1:1,000 in TBS-Tween) was added to membranes placed in a petri dish. After $1 \mathrm{~h}$ of incubation, the conjugate solution was discarded and membranes rinsed as before; the presence of bound antibody was visualized by the addition of substrate. The substrate consisted of $5 \mathrm{mg}$ of 5-bromo-3-chloro indolyl phosphatase dissolved in $100 \mu$ l of dimethyl formamide diluted in $30 \mathrm{ml}$ of substrate buffer $(0.1 \mathrm{M}$ Tris $\mathrm{HCl}, 01 \mathrm{M} \mathrm{NaCl}, 5 \mathrm{mM} \mathrm{MgCl} 2, \mathrm{pH}$ 9.5) containing $10 \mathrm{mg}$ of nitrobenzenetetrazolium. Reactions were terminated after 30 min by washing the membranes in distilled water.

A time course study was conducted by mechanically inoculating $I$. nil with isolate 95-2 (SPFMV-RC) and LSU-3 and -5 isolates. Samples were collected 7, 14, 21, 28, and 35 days after inoculation and tested by a modification of the triple-antibody sandwich ELISA (16) using the Moyer and Brunt antisera.

RNA extraction. Total RNA was extracted from $0.1 \mathrm{~g}$ of $I$. nil leaf tissue infected with each potyvirus isolate from sweet potato using TRIzol Reagent (Life Technologies, Inc., Grand Island, NY). Capsicum annuum cv. Yolo Wonder infected with a Louisiana isolate of Potato virus $Y$ was used as a control. Tissue was ground to a fine powder in liquid nitrogen and homogenized in $1.0 \mathrm{ml}$ of TRIzol reagent and $20 \mu \mathrm{l}$ of mercaptoethanol. After vortexing for 15 to $20 \mathrm{~s}$, the homogenate was incubated at $56^{\circ} \mathrm{C}$ for 5 $\min$, and centrifuged at $12,000 \times g$ at $4^{\circ} \mathrm{C}$ for $10 \mathrm{~min}$. The aqueous phase was incubated at room temperature for $5 \mathrm{~min}$. Chloroform $(200 \mu \mathrm{l})$ was added and the sample incubated at room temperature for 2 to $3 \mathrm{~min}$ and then centrifuged at $12,000 \times$ $g$ at $4^{\circ} \mathrm{C}$ for $15 \mathrm{~min}$. The aqueous phase was collected and $250 \mu \mathrm{l}$ of isopropyl alcohol and $250 \mu \mathrm{l}$ of salt mixture $(0.8 \mathrm{M}$ sodium citrate, $1.2 \mathrm{M}$ sodium chloride) were added to the solution. Total RNA was precipitated by centrifugation at $12,000 \times \mathrm{g}$ at $4^{\circ} \mathrm{C}$ for $10 \mathrm{~min}$. The RNA pellet was washed with $1.0 \mathrm{ml}$ of $75 \%$ ethanol and dissolved in $50 \mu \mathrm{l}$ of diethyl pyrocarbonate (DEPC)-treated water (Ambion, Austin, TX) and used as template for RT-PCR. Alternatively, double-stranded (ds)RNA was extracted from $3.5 \mathrm{~g}$ of infected tissues as described by Valverde et al. (30).

RT-PCR and cloning. Two primers sets were used. Set A consisted of degenerate primers POT1/POT2 and set B of POT1/PV2 (13-15). The nucleotide se- 
quence amplified by these two primer sets spans part of the NIb protein and part of the CP gene. The expected size of the DNA fragments amplified from SPFMV with primer sets $\mathrm{A}$ and $\mathrm{B}$ is 1.3 and $1.1 \mathrm{~kb}$, respectively. For the cDNA synthesis, $10 \mu \mathrm{l}$ of total RNA or dsRNA were denatured at $95^{\circ} \mathrm{C}$ for $3 \mathrm{~min}$ and kept on ice for $3 \mathrm{~min}$. Denatured RNA was mixed with $2 \mu \mathrm{l}$ of 10 $\mathrm{mM}$ of POT1, $200 \mathrm{U}$ of MMLV reverse transcriptase (Promega Corp., Madison, WI), and $2 \mu \mathrm{l}$ of $10 \mathrm{mM}$ dNTP mixture and incubated at $42^{\circ} \mathrm{C}$ for $40 \mathrm{~min}$. The cDNA $(25 \mu \mathrm{l})$ was used for PCR amplification after denaturing at $95^{\circ} \mathrm{C}$ for $3 \mathrm{~min}$. For the PCR reaction, $10 \mu \mathrm{l}$ of $10 \times$ PCR buffer (200 mM Tris-HCl, pH 8.4, $0.5 \mathrm{M} \mathrm{KCl}$ ), 4 $\mu \mathrm{l}$ of $50 \mathrm{mM} \mathrm{MgCl} 2,2 \mu \mathrm{l}$ of $10 \mathrm{mM}$ of primer POT2 or PV2, $59 \mu \mathrm{l}$ of $\mathrm{ddH}_{2} \mathrm{O}$, and $0.5 \mu \mathrm{l}$ (5 Units) of TaqDNA polymerase (Promega Corp.) were added to the $25 \mu \mathrm{l}$ of template. PCR was performed in an Amplitron II thermocycler (Thermolyne, Dubuque, IA) with five cycles (first), each consisting of $1 \mathrm{~min}$ at $95^{\circ} \mathrm{C}$ and $2 \mathrm{~min}$ at $40^{\circ} \mathrm{C}$, followed by 30 cycles of $1 \mathrm{~min}$ at $50^{\circ} \mathrm{C}$ and $3 \mathrm{~min}$ at $72^{\circ} \mathrm{C}$, and a final step of $10 \mathrm{~min}$ at $72^{\circ} \mathrm{C}$. The PCR products were separated by electrophoresis $(1.2 \%$ agarose) and stained with ethidium bromide. For each virus, bands corresponding to the expected PCR products were excised from agarose gels and further purified after electrophoresis using an UltraClean 15 DNA purification kit (MO BIO Laboratories Inc., Solana Beach, CA) and ligated into the pGEM-T vector (Promega Corp.). Recombinant plasmids were transformed into DH5 $\alpha$ Escherichia coli cells. The nucleotide sequences were determined by automated sequence analysis at the DNA Sequencing Core Laboratory, University of Florida, Gainesville (using an ABI337 DNA Sequencer; Perkin-Elmer, Foster City, CA). In all cases, at least three replicate PCR clones were sequenced to minimize error caused by Taq polymerase. Sequences were compared with others deposited in the GenBank database using the BLASTN 2.0.4 program (4).
Sequence comparisons and phylogenetic analyses. Nucleotide sequences obtained of the $3^{\prime}$ end of $\mathrm{NIb}$ and $5^{\prime}$ end of compared with counterparts of several strains of SPFMV and other members of the genus Potyviridae. Multiple sequence alignment was carried out using version 1.7 of the CLUSTAL W program (29). Percent identities and similarities between aligned nucleotide and derived amino acid sequences were determined using the equation $(100 \times$ sum of matching residues)/(length-gap residues [sequence 1] gap residues [sequence 2]) (7). Phylogenetic analyses using parsimony and the bootstrap option (100 replicates) were performed with version $3.5 \mathrm{c}$ of the Phylogeny Inference Package (PHYLIP) developed and distributed by J. Felsenstein (Department of Genetics, University of Washington, Seattle). Bootstrap values were shown using the $>50 \%$ majority rule. The phylogentic tree was based on the alignment of the N-terminal half of the $\mathrm{CP}$ (about 160 to 215 amino acids [aa]). Potyvirus sequences used were from the GenBank database with the following accession numbers: SPFMV-O (D16664), SPFMV-S (D38543), SPFMV-CH.S (S69825), SPFMV-CH.Z (S69826), SPFMVZim (AF016366), SPFMV-RUK (AJ010707), SPFMV-RAK (AJ010706), SPFMV-NIG3 (AJ010705), SPFMV-NAM1 (AJ010704), $\mathrm{CP}$ genes of each potyvirus isolate were

SPFMV-MAD (AJ010700), SPFMV-BAU (AJ010699), SPFMV-K1 (AF015540), SPFMV-K2 (AF015541), SPFMV-5 (U96624), SPFMV-6 (U96625), SPFMVRC (S43450), SPFMV-C (S43451), SPVG (X76944), SPMSV (U61228), SPMMV-1 (Z73124), Tobacco etch virus (TEV) (M11216), Potato virus Y-N (PVY-N) (D00441), and Lettuce mosaic virus (LMV) (AJ278854).

\section{RESULTS}

Host reactions. Each isolate induced chlorotic symptoms in a number of different Convolvulaceous host plants. However, distinctive symptoms were induced in some hosts. None of the virus isolates tested in this work induced symptoms of russet crack in Beauregard when inoculated singly. One isolate, 95-2, induced russet crack symptoms in Jersey, and isolate 95-6 was associated with mild internal cork symptoms in cv. Porto Rico planted in screen cages in the field. Several species of Ipomoea (I. alba, I. cordatotriloba, I. lacunosa, and I. hederifolia) were difficult to infect but, when infected, developed similar symptoms to those observed on $I$. setosa. Although there were differences in the symptoms on these hosts, they also displayed some similar symptoms and were difficult to distinguish. None of the isolates were able to infect $N$. rustica, $N$. tabacum cv. Turkish, or D. stramonium. A

Table 2. Frequency of transmission of sweet potato potyvirus isolates by single probes with Aphis gossypii or Myzus persicae

\begin{tabular}{lccc}
\hline & \multicolumn{2}{c}{ Transmission $^{\mathbf{a}}$} & \\
\cline { 2 - 3 } Isolate, source & A. gossypii & M. persicae & $\boldsymbol{P r}>\boldsymbol{F}$ \\
\hline Virus isolate & & & \\
LSU-1 & $12 / 56$ & $3 / 51$ & $\ldots$ \\
LSU-2 & $0 / 49$ & $0 / 47$ & $\ldots$ \\
LSU-5 & $0 / 52$ & $0 / 53$ & $\ldots$ \\
$95-2$ & $4 / 42$ & $10 / 43$ & $\ldots$ \\
Source & & & 0.0001 \\
$\quad$ Virus isolate & $\ldots$ & $\ldots$ & 0.2085 \\
Aphid species & $\ldots$ & $\ldots$ & 0.0066 \\
Isolate $\times$ aphid & $\ldots$ & $\ldots$ & 0.1129 \\
Replication & $\ldots$ & $\ldots$ &
\end{tabular}

a Positive transmissions/number attempted.

Table 1. Predominant symptoms observed on different plant hosts following inoculation with different potyviruses isolated from sweet potato ${ }^{\mathrm{a}}$

\begin{tabular}{|c|c|c|c|c|c|c|c|}
\hline \multirow[b]{2}{*}{ Potyvirus } & \multirow[b]{2}{*}{ Ipomoea nill } & \multirow[b]{2}{*}{ I. setosa } & \multirow[b]{2}{*}{ I. tricolor ${ }^{\mathrm{d}}$} & \multirow[b]{2}{*}{ Chenopodium quinoa } & \multirow[b]{2}{*}{ Nicotiana benthamiana } & \multicolumn{2}{|c|}{ Beauregard with SPCSV ${ }^{b}$} \\
\hline & & & & & & Synergism & Symptoms \\
\hline LSU-1 & Mt & $\mathrm{CS}$ & $\mathrm{CS}$ & NS & Var. (NS -R/VC) & $?$ & CLP \\
\hline LSU-2 & VnMs & VnMs & VnMs & CLL-7 & $\mathrm{VC}$ & + & $\mathrm{Cs}, \mathrm{Pu}, \mathrm{VnN}, \mathrm{St}$ \\
\hline LSU-3 & Mt & $\mathrm{CS}$ & $\mathrm{CS}$ & NS & $\mathrm{NS}-\mathrm{R}$ & $?$ & CLP \\
\hline LSU-5 & VnMs & VnMs & VnMs & CLL-7 & $\mathrm{VC}$ & + & $\mathrm{Cs}, \mathrm{Pu}, \mathrm{VnN}, \mathrm{St}$ \\
\hline $95-2$ & FMt & FMt & VC, W, D & CLL-10 & $\mathrm{NS}-\mathrm{R}$ & + & $\mathrm{FL}, \mathrm{Ms}, \mathrm{St}$ \\
\hline FMV-C & $\mathrm{Cr}, \mathrm{FMt}$ & FMt & Mt & NS & $\mathrm{NS}+\mathrm{R}$ & - & MMt \\
\hline
\end{tabular}

a Abbreviations for symptoms: $\mathrm{Cr}=$ crinkling; $\mathrm{CS}=$ chlorotic spotting; $\mathrm{VnMs}=$ vein mosaic; $\mathrm{FMt}=$ feathery mottle; $\mathrm{St}=$ stunting; $\mathrm{W}=$ wilting; $\mathrm{D}=$ death; CLL-7 = chlorotic local lesions first appearing at about 7 days; CLL-10 = chlorotic local lesions first appearing at about 10 days; CLP = chlorotic line pattern; FL = fan-leaf shape; $\mathrm{Ms}=$ mosaic; $\mathrm{Mt}=$ mottle; $\mathrm{MMt}=$ mild mottle; $\mathrm{Pu}=$ puckering; Var. $=$ variable; $\mathrm{VC}=\mathrm{vein}$ clearing; $\mathrm{VnN}=$ vein necrosis; NS = no symptoms; $+\mathrm{R}=$ recovered by back inoculation to Scarlet O'Hara, and $-\mathrm{R}=$ not recovered.

${ }^{\mathrm{b}}$ Synergism in Beauregard infected with the White Bunch isolate of Sweet potato chlorotic stunt virus (SPCSV) resulted in severe symptoms including stunting of leaf and vine growth.

' Cv. Scarlett O'Hara.

${ }^{\mathrm{d}} \mathrm{Cv}$. Heavenly Blue. 
strong synergism on Beauregard was obtained when isolates LSU-2 and -5 or isolate 95-2 were present as double infections with SPCSV (Table 1). However, the symptoms differed qualitatively: the 95-2SPCSV combination induced typical SPVD (16) symptoms, including stunting, general chlorosis, fan-leaf, and mosaic; whereas the LSU-2 or -5-SPCSV combination induced severe chlorotic spotting, leaf distortion, and vein discoloration. Milder symptoms were obtained with the other isolates tested.

Aphid transmission. LSU-1 was transmitted by both aphid species but at a higher frequency by A. gossypii than by $M$. persicae, whereas isolate 95-2 of SPFMV was transmitted at a higher frequency by M. persicae (Table 2). Isolates LSU-2 and -5 were not transmitted by either $A$. gossypii or $M$. persicae in approximately 50 attempts for each combination. LSU-3 was transmitted by A. gossypii (5/40) but not by $M$. percicae (0/45); however, because LSU-3 experiments were not conducted simultaneously, they were not included in the statistical analysis as shown in Table 2.

Potyvirus-like particles and potyvirus inclusions. Cylindrical inclusion bodies, which consisted of pinwheels, and scrolls were observed in the cytoplasm of epidermal, mesophyll, and vascular cells of $I$. nil and $I$. setosa that had been graft-inoculated with scions infected by LSU-1, -3 , and -5 . These inclusions were similar to those reported in cells of plants infected with SPFMV (11). Neither inclusion bodies nor particles were found in the cell organelles of infected plants. Inclusions or abnormal structures were not present in the cytoplasm of cells of noninoculated plants, except for crystalline inclusions that occurred occasionally in the nucleus of leaf hairs and trichomes of healthy I. nil.

Serology. In nitrocellulose membrane (NCM)-ELISA tests, isolate LSU-1, -2, -3, and -5 did not react with any of the antisera provided by CIP (SPFMV, SPMMV, SwPLV, SPCFV, SPMSV, or C-6). Weak reactions were obtained with Moyer's antiserum to SPFMV-SRC cross absorbed with healthy sap. LSU-2 and -5 reacted positively with Brunt's antiserum \#1395 cross absorbed with healthy sap. Tripleantibody sandwich ELISA results are shown in Figure 1. Only LSU-5 reacted with antiserum \#1395. 95-2 (SPFMV-RC) reacted strongly with SPFMV-RC antiserum throughout the test period and LSU5 gave an intermediate reaction, especially at 21 days after inoculation, whereas LSU3 did not react with either antiserum.

Amplification by RT-PCR. Using universal primers derived from the NIb and $\mathrm{CP}$ genes of the potyviral genome, RT-PCR products of the expected size were obtained. DNA fragments of about $1.3 \mathrm{~kb}$ were amplified by primer set A (POT1/POT2) from RNA extracts of plants infected with PVY, SPFMV-C, and SPFMV-RC and isolates 95-2, 95-6, and LSU-2 and -5. However, this primer set did not amplify DNA from the LSU-1 and -3 isolates. Primer set B (POT1/PV2) did amplify a 1.1-kb fragment from the latter two isolates. Although some RT-PCR products from each individual virus sample contained multiple bands ( 0.8 to $2 \mathrm{~kb}$ ), DNA fragments of expected size were amplified in larger quantities. DNA fragments were not obtained when RT-PCR was conducted using RNA extracts from healthy plants. All isolates could be detected by PCR; however, results were not consistent. Occasionally, RT-PCR failed to detect these potyviruses from infected $I$. setosa plants.

Sequence analysis. Analysis of the nucleotide sequences of cloned RT-PCR products confirmed that the sequence corresponded to a region of the potyviral genome that included part of the $3^{\prime}$ end of the NIb gene and of the $5^{\prime}$ half of the CP gene.

The nucleotide sequences and derived amino acid sequences of the combined partial NIb and CP genes of the LSU-1 and -3 isolates were nearly identical. The region corresponding to the $\mathrm{CP}$ gene of these two viruses had 98 and $100 \%$ identity in nucleotide and amino acid sequences,
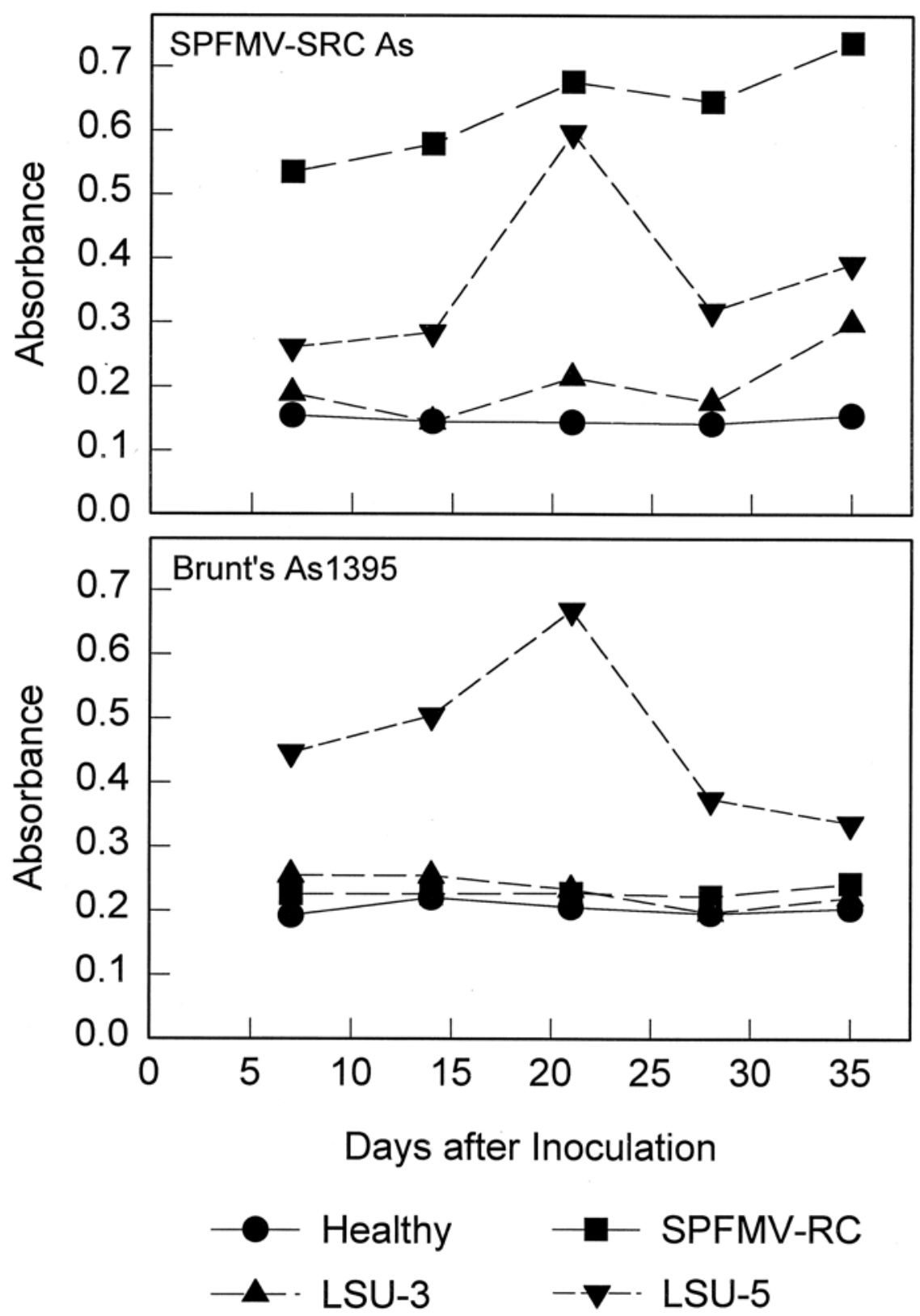

Fig. 1. Graphs of absorbance values from triple-antibody sandwich enzyme-linked immunosorbent assays. Leaf tissue from plants of Ipomoea nil cv. Scarlet O'Hara collected at different times following mechanical inoculation with 95-2, a russet crack isolate of Sweet potato feathery mottle virus (SPFMV-RC), LSU-3, or LSU-5 was compared with healthy controls using Moyer's antiserum produced to a severe isolate of SPFMV-RC (SPFMV-SRC; top) or Brunt's antiserum (\#1395) produced to a partially characterized potyvirus from sweet potato (bottom). 
respectively, when compared with the $\mathrm{CP}$ gene of SPVG. Isolate LSU-2 had 95\% identity in nucleotide and $100 \%$ identity in amino acid sequence when compared with LSU-5. Comparisons of the nucleotide sequences of LSU-1 and -5 showed $66 \%$ identity. The region corresponding to the $\mathrm{NIb}$ gene from LSU-1 and -5 was more conserved than the $\mathrm{CP}$ regions. The derived amino acid sequences corresponding to the $\mathrm{NIb}$ gene had $89 \%$ identity while the sequences corresponding to the $\mathrm{CP}$ gene had $62 \%$ identity.
The derived amino acid sequences of the RT-PCR products of the LSU isolates were compared with various strains of SPFMV and other potyviruses. There was an extensive similarity in the C-terminus of the NIb region of all four LSU isolates with that of strains of SPFMV and other potyviruses. All derived amino acid sequences of the four isolates contained the proteinase cleavage site, found in SPFMV and other potyviruses $(1,2)$. The phylogenetic relationships between the four LSU potyviruses, 17 strains of SPFMV, and five other members of Potyviridae was analyzed based on the derived amino acid sequences of the $\mathrm{N}$-terminal of the $\mathrm{CP}$ gene (160 to 215 aa) (Fig. 2). The phylogenetic tree (Fig. 2) separated the sweet potato potyviruses from other members of that family. The four LSU isolates were placed apart from the cluster that contained mainly SPFMV strains. LSU-1 and -3 grouped together and were more closely related to SPVG and SPMSV than to LSU2 and -5 . The similarity between LSU-1 and -3 and SPVG was clearly seen in the

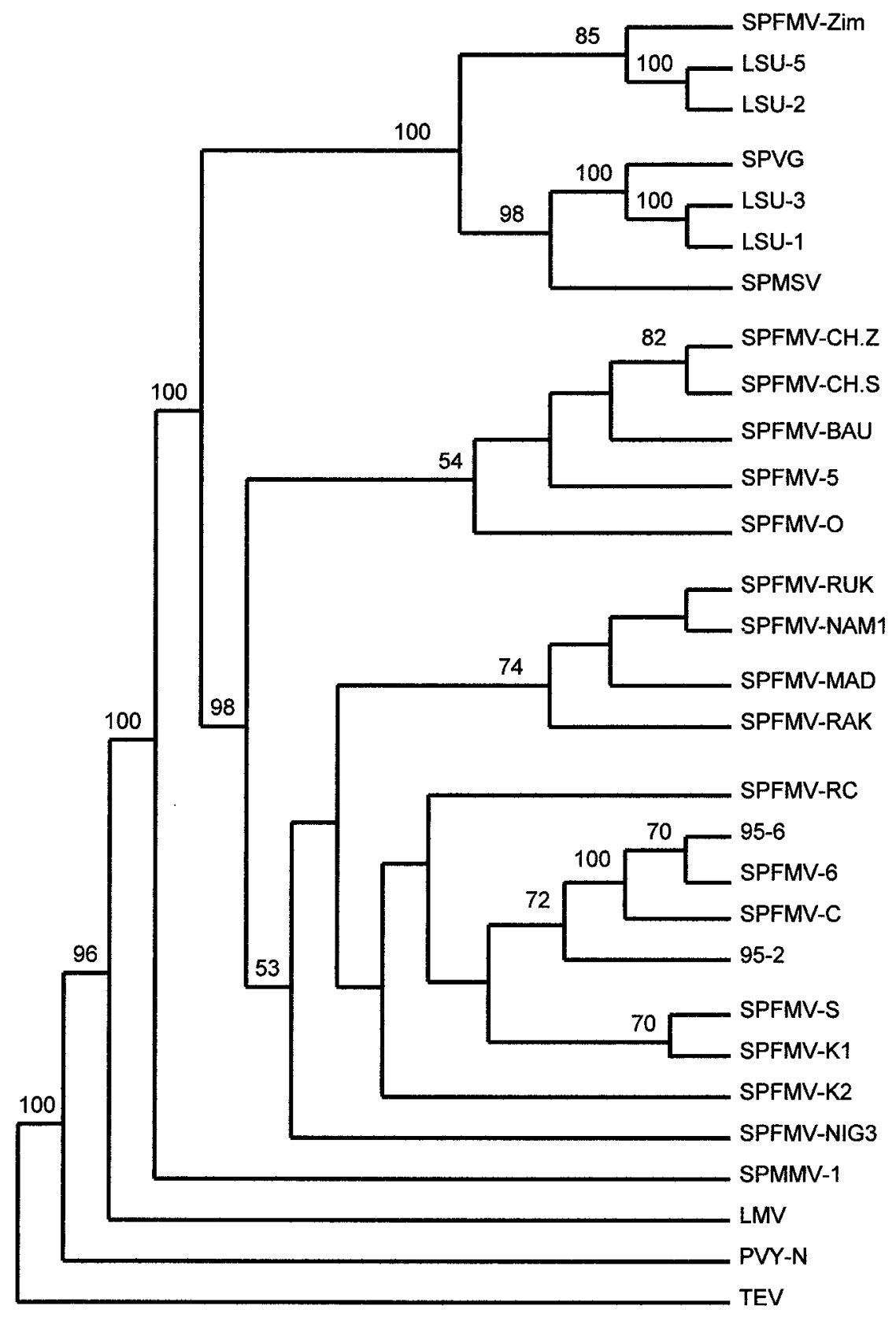

Fig. 2. Phylogenetic tree showing the relationship between the four LSU potyviruses and other members of the family Potyviridae based on multiple sequence alignment of the derived N-terminal amino acid sequence of the coat protein. The tree was constructed using programs in the CLUSTAL W package (version 1.7). The significance $(>50 \%)$ of the modes in a bootstrap analysis with 100 replicates is shown. Vertical distances are arbitrary. Horizontal distances reflect genetic distance between branch nodes. Tobacco etch virus (TEV) was used as an outgroup. Selected viruses included: various strains of Sweet potato feathery mottle virus (SPFMV) including SPFMV-95-2, SPFMV-95-6, SPFMV-C, SPFMV-O, SPFMV-S, SPFMV-CH.S, SPFMVCH.Z, SPFMV-Zim, SPFMV-RUK, SPFMV-RAK, SPFMV-NIG3, SPFMV-NAMI, SPFMV-MAD, SPFMV-BAU, SPFMV-K1, SPFMV-K2, SPFMV-5, SPFMV-6, SPFMV-RC, Sweet potato virus G (SPVG), Sweet potato mild mottle virus (SPMMV-1), Sweet potato mild speckling virus (SPMSV), Potato virus Y-N (PVY-N), and Lettuce mosaic virus (LMV). 
alignment of the derived amino acid sequences of part of the N-terminal region of the CP gene (Fig. 3). LSU-2 and -5 were closely related to each other and more closely related to sweet potato potyviruses than to other potyviruses, but formed a distinct group together with SPFMV-Zim. Isolates LSU-2 and -5 and SPFMV-Zim contained a similar 22-aa sequence at the N-terminus which is lacking in other SPFMV strains (Fig. 3). Within the group that included the SPFMV strains, several distinct clusters were obtained, one containing strains from China, Nigeria, Japan, and Argentina; another containing East African strains; and one containing SPFMV-C, which included isolates 95-2 and 95-6, SPFMV-RC, and other SPFMV isolates.

\section{DISCUSSION}

Mechanically transmitted viruses isolated from sweet potato frequently are designated as strains of SPFMV. This usually is based on the symptoms induced on I. setosa, serological reaction using polyclonal antisera, and aphid transmissibility. However, the availability of more information on nucleotide sequence, strain-specific antisera, and host reaction suggests that some of these strains could be distinct potyviruses $(10,12-14,20,22)$. In this investigation, some potyviruses isolated from sweet potato had properties that clearly distinguished them from SPFMV while others appear to be strains of SPFMV.

SPFMV isolates 95-2 and 95-6 included in this study originated from Beauregard sweet potato showing russet crack (RC) symptoms. Although isolate 95-2 caused $\mathrm{RC}$ in Jersey, it did not induce RC under the same conditions in Beauregard. Attempts to experimentally reproduce $\mathrm{RC}$ symptoms in Beauregard with 10 other isolates were similarly unsuccessful (C. A. Clark, unpublished data). Some explanations could be genetic differences in the cultivar, environmental conditions, low virus titer, or irregular distribution in the source of inoculum. It also is possible that $\mathrm{RC}$ is caused in Beauregard by a different strain of SPFMV, a combination of viruses, or even an entirely different virus from the SPFMV-RC that causes RC in cv. Jersey. Moreover, the virus isolates inoculated in
Beauregard were obtained by single aphid probe, which excludes the possible detection of agents not transmitted by aphids that might be associated with RC symptoms. Cv. Jersey and Chenopodium spp. are reported to be useful in differentiating RC-inducing strains of SPFMV from the common strain (9). The host range and symptoms induced by $95-2$ in $C$. quinoa and Jersey suggest that this isolate is a strain of SPFMV-RC, which was supported by sequence information.

Sweet potato internal cork is thought to be induced by SPFMV (11). However, the viral etiology of this disease has not been confirmed (5). The internal cork symptoms induced by $95-6$ in the sweet potato cv. Porto Rico were very mild and inconsistent and may indicate that this virus does not induce the full internal cork syndrome by itself. Partial sequence information suggested that this isolate is a strain of SPFMV-C.

The symptoms induced in different hosts by $95-2$ and FMV-C were consistent with those reported previously for the RC and common strains, respectively, of SPFMV $(8,23)$. The symptoms induced by LSU-1 and -3 were indistinguishable from each other, but distinct from those produced by the strains of SPFMV, especially in $I$. setosa, in which they induced only very mild, transient chlorotic spotting that developed later than symptom development for SPFMV. Likewise, LSU-2 and -5 were indistinguishable but distinct from all the other potyviruses tested.

Kreuze et al. (20) compared the CP sequences of SPFMV isolates from East Africa with 10 isolates from other continents. Isolates formed four groups: group EA (East African isolates), group RC (russet crack strain), group O (SPFMV-O), and group C (SPFMV-C). Isolates of group C were distantly related to all the other isolates. The tree generated in the present study included the EA and the $\mathrm{O}$ group; however, SPFMV-C, RC, and other strains formed a cluster that included 95-2 and 956 . Other sweet potato potyviruses did not cluster with the 16 SPFMV strains. These included four LSU isolates, SPVG, and SPFMV-Zim. The collection of potyvirus isolates used for this study suggests not only that at least two strains of SPFMV occur in the United States, but that two other potyviruses also are present. LSU-1 and -3 shared high levels of sequence identity with the published sequences for SPVG (14), did not react with antisera to other known sweet potato viruses, and induced distinct and milder symptoms in several hosts compared with the other sweet potato potyviruses. Unfortunately, no information has been published on properties of SPVG other than CP sequence; therefore, it is not possible to compare the biological properties determined here. Nevertheless, we propose to designate these two isolates as SPVG and this study documents the occurrence of this virus in the United States and provides the first characterization of its biological properties.

LSU-2 and -5 appear to be distinct in symptomatology and $\mathrm{CP}$ sequence and reacted only with an antiserum (\#1395) to a potyvirus partially described by Brown et al. (6). They induced strong synergism in Beauregard with SPCSV, but the synergistic symptoms were distinct from the SPVD symptoms induced by SPCSV and SPFMV-RC. It is possible that this virus is related to one of the many viruses reported in the literature from sweet potato that either have not been thoroughly characterized or for which there are no longer reference cultures available, such as Sweet potato vein mosaic virus (26) or the potyvirus called Sweet potato chlorotic stunt virus (6). LSU-2 and -5 are similar to the brief description of the latter virus in that they react with the \#1395 antiserum and were not transmitted by aphids, but the description of Brown et al. (6) indicates that their virus infected a broad range of hosts. These two LSU isolates clustered together with SPFMV-Zim in a distinct branch of the phylogenetic tree constructed using the $\mathrm{N}$-terminus region of the $\mathrm{CP}$ gene. LSU-2 and -5 and SPFMV-Zim each contained a similar 22-aa sequence at the $\mathrm{N}$-terminus which is lacking in other SPFMV strains compared in this and other studies (10). Isolates LSU-2 and -5 did not react as strongly as 95-2 with SPFMV-RC antiserum and only very weakly with the SPFMV antiserum in the CIP NCMELISA kit, while SPFMV-Zim has a close serological relationship with SPFMV-RC

SPEMV-RC
SPEMV-CH.Z
LSU-2
LSU-5
SPEMV-Zim
SPEMV-C
LSU-1
ISU-3
SPVG

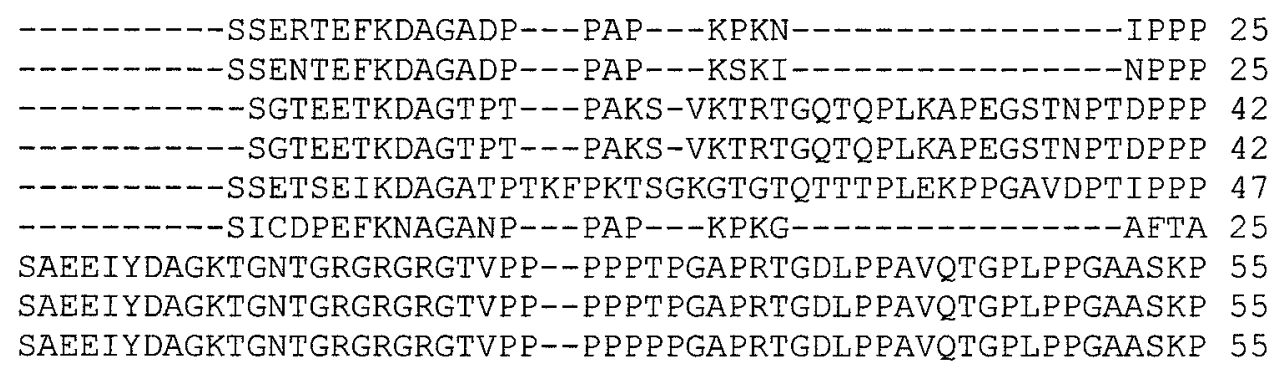

Fig. 3. Multiple alignment of the amino acid sequences of part of the N-terminal region of the coat protein gene of isolates LSU-1, -2 , -3 , and -5 with the corresponding sequences of Sweet potato virus G (SPVG) and the Zimbabwe (Zim), russet crack (RC), China (CH.Z), and common (C) strains of Sweet potato feathery mottle virus (SPFMV). Dashes indicate deleted amino acids. 
(10). We propose to call this virus (isolates LSU-2 and -5) Ipomoea vein mosaic virus (IVMV).

The present study revealed a high degree of similarity between 95-6 and SPFMV-C. This suggests that 95-6 is an isolate of the common strain of SPFMV. Despite the fact that host range sometimes is cited as being of secondary value for potyvirus taxonomy after $\mathrm{CP}$ sequence data, the results of this study show similar groupings of the isolates using symptomatology and sequencing data. Moreover, it suggests that, before naming a new SPFMV strain based solely on nucleic acid sequence, information on biological properties, including host range and symptomatology, is desirable in order to support strain nomination.

All the isolates sequenced in this study contained the 3-aa motif, asp-ala-gly (DAG), at the $\mathrm{N}$ terminus of the $\mathrm{CP}$, which is associated with aphid transmissibility (2). Nevertheless, LSU-2 and -5 were not transmitted by aphids from singly infected plants. Results obtained by Lopez-Moya et al. (21) with Tobacco vein mottling virus and TEV, two aphid-transmitted potyviruses, suggest that the mere presence of a DAG motif does not guarantee transmissibility. Instead, the context in which the DAG or equivalent motif is found plays a role in the transmission process. Studies are in progress to determine if these isolates, although they are not transmitted by aphids from singly infected plants, may be transmitted from plants infected with other potyviruses.

It has been demonstrated that distribution of SPFMV along the length of sweet potato vines is irregular $(3,17)$. In some cases, SPFMV can be detected in some leaves along a vine but not in others. Changes in virus concentration throughout the plant over time also cause problems (5). RT-PCR did not reproducibly succeed in detecting SPFMV in plants known to be infected; thus, the methods used do not support the use of RT-PCR in routine diagnosis of sweet potato viruses. However, it has some advantages, because it can amplify viruses present in low concentrations, such as SPFMV. Amplicons could be generated for all the isolates by this method, and genetic material was obtained for further molecular characterization, without the need of virus purification. SPFMV and, probably, other sweet potato viruses are representatives of some of the most difficult viruses to work with. Several methods that currently are available for virus detection can be adopted, with some modifications, for sweet potato virus detection from symptomatic Ipomoea spp. However, this work demonstrated that sometimes even symptomatic plants escape detection. An ideal method for diagnosis of sweet potato viruses must rely on consistency of results and capability to detect virus from symptomless infected plants. At the same time, those methods should not be too expensive in order to be accessible to most worldwide sweet potatoproducing areas.

\section{ACKNOWLEDGMENTS}

We thank J. W. Moyer, North Carolina State University, for providing the SPFMV-C isolate and SPFMV-SRC antiserum; S. Fuentes and L. Salazar, the International Potato Center, for providing NCM-ELISA kits; A. Brunt, Littlehampton, UK, for providing antiserum \#1395; the Louisiana Sweet Potato Commission, the USDA-APHIS, and the International Potato Center for partial financial support; the National Research Council of Brazil $(\mathrm{CNPq})$ for financial support for E. R. Souto during his stay at Louisiana State University; M. W. Hoy for expert technical assistance; L. McKoin for assistance with aphid transmissions; and J. W. Moyer, J. Abad, L. Salazar, S. Fuentes, and S. Hurtt for helpful discussions.

\section{LITERATURE CITED}

1. Abad, J. A. 1991. Molecular characterization and detection of the capsid protein gene from two serologically distinct strains of sweet potato feathery mottle virus (SPFMV). PhD. thesis, North Carolina State University, Raleigh.

2. Abad, J. A., Conkling, M. A., and Moyer, J. W. 1992. Comparison of the capsid protein cistron from serologically distinct strains of sweet potato feathery mottle virus (SPFMV). Arch. Virol. 126:147-157.

3. Abad, J. A., and Moyer, J. W. 1992. Detection and distribution of sweetpotato feathery mottle virus in sweetpotato by in vitro-transcribed RNA probes (riboprobes), membrane immunobinding assay, and direct blotting. Phytopathology 82:300-305.

4. Altschul, S. F., Thomas, L. M., Alejandro, A. S., Jinghui, Z., Zheng, Z., Webb, M., and David L. 1998. Gapped BLAST and PSIBLAST: a new generation of protein database search programs. Nucleic Acids Res. 25:33893402.

5. Beetham, P., and Mason, A. 1992. Production of pathogen-tested sweet potato. ACIAR Tech. Rep. No. 21, Canberra, Australia.

6. Brown, J. D., Brunt, A. A., and Hugo, S. A. 1988. Studies on viruses isolated from sweet potato (Ipomoea batatas). Pages 104-108 in: Rep. Glasshouse Crops Res. Inst. 1986-87.

7. Brown, J. K., Ostrow, K. M., Idris, A. M., and Stenger, D. C. 1999. Biotic, molecular, and phylogenetic characterization of bean calico mosaic virus, a distinct Begomovirus species with affiliation in the squash leaf curl virus cluster. Phytopathology 89:273-280.

8. Cadena-Hinojosa, M .A., and Campbell, R. N. 1981. Characterization of isolates of four aphid-transmitted sweet potato viruses. Phytopathology 71:1086-1089.

9. Cali, B. B., and Moyer, J. W. 1981. Purification, serology, and particle morphology of two russet crack strains of sweet potato feathery mottle virus. Phytopathology 71:302-305.

10. Chavi, F., Robertson, A. I., and Verduin, B. J. M. 1997. Survey and characterization of viruses in sweet potato from Zimbabwe. Plant Dis. 81:1115-1122.

11. Clark, C. A., and Moyer, J. W. 1988. Compendium of Sweet Potato Diseases. The American Phytopathological Society Press, St. Paul, MN.

12. Colinet, D. 1996. Identification and molecular characterization of potyviridae in Sweet potato using Polymerase Chain Reaction (PCR) These de doctorat, Faculte Universitaire des Sciences Agronomiques, Gembloux, Belgium.

13. Colinet, D., and Kummert, J. 1993. Identification of a sweet potato feathery mottle virus isolate from China (SPFMV-CH) by the polymerase chain reaction with degenerate primers. J. Virol. Methods 45:149-159.

14. Colinet, D., Nguyen, M, Kummert, J., and Lepoivre, P. 1998. Differentiation among potyviruses infecting sweet potato based on genus- and virus-specific reverse transcription polymerase chain reaction. Plant Dis. 82:223229.

15. Gibbs A, and Mackenzie, A. 1997. A primer pair for amplifying part of the genome of all potyvirids by RT-PCR. J. Virol. Methods 63:9-16.

16. Gibson, R. W., Mpembe, I., Alicai, T., Carey, E. E., Mwanga, R. O. M., Seal, S. E., and Vetten, H. J. 1998. Symptoms, aetiology and serological analysis of sweet potato virus disease in Uganda. Plant Pathol. 47:95-102.

17. Green S. K., Kuo Y. J., and Lee D. R. 1988. Uneven distribution of two potyviruses (feathery mottle virus and sweet potato latent virus) in sweet potato plants and its implication on virus indexing of meristem derived plants. Trop. Pest Manag. 34:298302.

18. Hammond, J., Jordan, R. L., Larsen, R. C., and Moyer, J. W. 1992. Use of polyclonal antisera and monoclonal antibodies to examine serological relationships among three filamentous viruses of sweetpotato. Phytopathology 82:713-717.

19. Jester, W. R., Averre, C. W. and Schultheis, J. R. 1994. Russet crack-like symptoms in 'Beauregard' sweetpotato reduced by virus indexing and micropropagation. (Abstr.) HortScience 29:727.

20. Kreuze, J. F., Karyeijea, R. F., Gibson, R. W., and Valkonen, J. P. T. 2000. Comparison of coat protein gene sequences show that East African isolates of Sweet potato feathery mottle virus form a genetically distinct group. Arch. Virol. 145:567-574.

21. Lopez-Moya, Wang, R. Y., and Pirone, T. 1999. Context of the coat protein DAG motif affects potyvirus transmissibility by aphids. J. Gen. Virol. 80:3281-3288.

22. Moyer, J. W., Abad, J., New, J., and Bell, J. 2002. Isolation, identification and detection of undescribed RNA sweetpotato viruses. Acta Hortic. 583:121-127.

23. Moyer J. W., Cali B. B., Kennedy, G. G., and Abu-Ghadir, M. F. 1980. Identification of two sweet potato feathery mottle virus strains found in North Carolina. Plant Dis. 64:762-764.

24. Moyer, J. W., and Salazar, L. F. 1989. Viruses and virus-like diseases of sweet potato. Plant Dis. 73: 451-455.

25. Nishiguchi, M., Mori, M., Suzuki F., Nagata, R., Morishita T., Sakai J., Hanada, K., and Usugi T. 1995. Specific detection of a severe strain of sweet potato feathery mottle virus (SPFMV-S) by Reverse Transcription and Polymerase Chain Reaction (RT-PCR). Ann. Phytopathol. Soc. Jpn. 61:119-122.

26. Nome, S. F. 1973. Sweet potato vein mosaic in Argentina. Phytopathol. Z. 77:44-54.

27. Salazar, L. F., and Fuentes, S. 2001. Current knowledge on major virus diseases of sweet potatoes. Pages 14-19 in: Proc. Int. Workshop Sweetpotato Cultivar Decline Study. Y. Nakazawa and K. Ishiguro, eds. Kyushu Nat. Agric. Exp. Stn. Miyakonojo, Japan.

28. Scott, G. J., Rosegrant, M. W., and Ringler, C. 2000. Roots and Tubers for the 21st Century: Trends, Projections, and Policy Options. IFPRI. Lima, Peru.

29. Thompson, J. D., Higgins, D. G., and Gibson, T. J. 1994. Clustal W: Improving the sensitivity of progressive multiple sequence alignment through sequence weighting, positionsspecific gap penalties and weight matrix choice. Nucleic Acids Res. 22:4673-4680.

30. Valverde, R. A., Nameth, S. T., and Jordan, R. L. 1990. Analysis of double-stranded RNA for plant virus diagnosis. Plant Dis. 74:255-258. 